\title{
UDC 639:616.982.17
}

KRYLENKO S.Y., e-mail: vet@ivm.kiev.ua,

TARASOV O.A., PhD in Vet. Sc., Senior Researcher, e-mail: vet@ivm.kiev.ua, GUDZ N.V., PhD in Vet. Sc., Senior Researcher, e-mail: gudznatalya @ gmail.com, BABKINA M.M., e-mail: pharmwork@ukr.net.ua, TERESCHENKO S.M., e-mail: vet@ivm.kiev.ua Institute of Veterinary Medicine of the NAAS

\section{INFLUENCE OF AMINOACIDS ON BACILLUS GENUS BACTERIA SPORE GERMINATION}

The study applies experimental approaches to spore germination to determine whether the germinants will affect the two different species B. cereus and B. anthracis using in vitro tests.

Carrying out studies on the vaccine strain of the $B$. anthracis, we used different combinations of amino acids to study possible ways to improve spore germination. The best results were obtained using inosine and L-serine as well as inosine with L-alanine and L-valine $(0.1 \mathrm{mM}$ aqueous solution of an equal ratio of amino acids was used).

Analysis of the results of the studies showed that part of spores germinated in nutrient media after treatment with a mixture of amino acids reached $86.2 \%$ compared with $58 \%$ in the control. The variability of these values for tested strains ranged from $\pm 3.8 \%$ to $\pm 13.6 \%$.

We also found that the percentage of germinated spores does not increase significantly in time after the first 48 hours from the start of cultivation

Keywords: spore germination, Bacillus species, aminoacids, germinant.

Introduction. Bacillus species are rod-shaped, gram-positive bacteria that are capable of producing endospores. In this dormant stage, the endospores can persist in hostile physical and chemical environments. Once conditions become favorable, the spores germinate into actively dividing cells, vegetative cells. Germination is a crucial step for the pathogenicity of the Bacilli in affecting a host organism [1].

$B$. anthracis is the causative agent of anthrax, a dangerous disease of human and animals, especially ruminants. Animals can be infected through exposure to spores in contaminated grazing areas, contaminated feed, or infected carcasses. Humans in agricultural settings can be infected through contact with infected animals or contaminated animal products. In Ukraine, even at the beginning of the 21st century, anthrax is a revelant issue for humans and animals nationwide, which has long time history. Infected carcass can be a source of spores, and spores have been known to reinfect animals over 70 years after the burial of the originally infected animal $[2,3]$.

Bacillus species are present in two different physiological states: vegetative cell and the endospore. The bacterial endospore is one of the most resistant and dormant life forms, it can be much more heat resistant than the vegetative form of the same species [4]. Spores have a highly dense and structured morphology that contributes to its resistant capacities. Chemical resistance of the spore is dependent on the protection of the spore coat and inner membrane, dehydration of the spore core, and by small, acid-soluble proteins [5]. 
When specific nutrients are present in sufficient quantities, bacterial cells continue the normal vegetative growth and proliferate. Once these nutrients are depleted, bacteria initiate the sporulation program as a response to starvation. When nutrients return to the environment, the bacterial spore germinates and resumes normal vegetative growth. The survival of a spore is dependent on its ability to germinate into a metabolically active growing vegetative cell $[5,6]$.

$B$. cereus, B. anthracis, B. thuringiensis and B. mycoides share significant degree of genetic similarity based on DNA-DNA hybridization studies [6, 7]. It was reported that the four species exhibit greater than $99 \%$ similarity in their $16 \mathrm{~S}$ rRNA base sequences [8,9]. B. cereus has seven ger operons (gerQ, gerG, gerK, gerL, gerS, gerl, gerR). The gerL operon is the major contributor for the germination of $B$. cereus spores with L-alanine as a sole germinant [10]. The gerI operon responds to both the addition of L-alanine and inosine to trigger the germination response [11]. B. anthracis germination receptors and their germinants have been well studied [12].

The goal of the work. The study applies experimental approaches to spore germination to determine whether the germinants will affect the two different species, $B$. cereus and B. anthracis using in vitro tests.

Materials and methods of research. In the study it was used Bacillus anthracis (UA 07), Bacillus cereus (ATCC 10702) from the collection of the Institute of Veterinary Medicine of the NAAS (IVM).

Bacterial strains were grown in Brain Heart Infusion (BHI) and subcultivated on agar plates (BioRad). The pure cultures were prepared on $\mathrm{BHI}$ agar plates at $37^{\circ} \mathrm{C}$ for 5 days, collected with brain heart infusion and $50 \%$ glycerol solution at a ratio of $1: 1$, and stored as stock cultures for further tests.

Bacterial endospore extraction and screening was carried out under careful precautions in the laboratory of the IVM, according to the OIE manual (2004) and SOPs. The culture in tube $(5.0 \mathrm{ml})$ was treated with $70 \%$ ethanol to decontaminate all microorganism exept spores for 10 minutes. Then it was added $5 \mathrm{ml}$ of PBS and manually stirred for $5 \mathrm{~min}$. After that, it was centrifuged for 2-3 min at $3000 \mathrm{~g}$. The decantated suspension was used for further tests.

A spore suspension in distilled water was filtered through $0.45 \mu \mathrm{m}$ filter and the deposit on the filter was suspended in sterile PBS. The aliquot was heated at $65^{\circ} \mathrm{C}$ for 20 minutes to destroy vegetative cells. Then the suspension was centrifuged and the pellet reconstituted in about $2 \mathrm{ml}$ of sterile PBS. The resuspended pellet was streaked on the agar media. Colonies emerging at the end of 24-48 hours incubation were examined for morphological and cultural features. The identity of isolated colonies according to morphology on the plates was tested by microscopy with Gram-staining.

The final inoculum was approximately $2 \times 10^{3} \mathrm{CFU} / \mathrm{ml}$, as determined from the colony counts for the growth control well.

Because spores have a highly dense structure, they scatter light strongly. Upon germination the spore core hydrates, which reduces light scattering. This property was used to measure germination by following the decrease in optical density at $540 \mathrm{~nm}$ (OD540) of a spore suspension after exposure to germination conditions. The 
spores were re-suspended in PBS twice and a finally re-suspended in PBS solution with aminoacisd to an OD540 of 1.0 as measured in a spectrophotometer.

Spore suspension was diluted 10 fold up to $10^{-6}$ dilution and streaked on BHI agar and incubated for $48 \mathrm{hr}$. Then the number of colonies was counted and evaluated against control samples without aminoacids.

Spores obtained were subjected to germination with $0.1 \mathrm{mM}$ concentration of different combinations of aminoacids: L-proline, L-alanine, L-histidine, Ltryptophan, L-tyrosine, L-phenylalanine, L-valine and inosine. These concentrations were chosen according to the literature data [13, 14].

Results of research and discussion. Both $B$. cereus and $B$. anthracis germinated with a variety of amino acids. B. cereus showed to have cooperative effects with inosine and L-alanine induced germination. We studied the effects of inosine and L-alanine germination in response to cooperative binding. We showed that allosteric cooperativity is seen with the inosine and L-alanine binding sites between the GerI and GerQ receptors. With B. anthracis, we used 10 different combinations of amino acid and nucleosides to understand the different pathways of germination response. We suggest a mechanism of binding that requires cooperativity among inosine with L-valine and inosine with L-serine binding.

When B. cereus spores were treated with solution of inosine and L-alanine, the maximum germination rate changed with increasing inosine concentrations. Similarly, the affinity of $B$. anthracis spores for L-valine and L-serine increased with increasing inosine concentrations.

All the cyclic compounds tested besides L-histidine (L-proline and aromatic amino acids: L-tryptophan, L-tyrosine, and L-phenylalanine) showed no significant germination at physiological substrate concentrations. This includes L-proline in combination with inosine and in combination with L-alanine.

These studies have shown that few combinations of the germinants have showed up to $86.2 \%$ of germination within the first $24 \mathrm{hrs}$.

As a result of the studies it was found that $B$. cereus and $B$. anthracis have improved germination properties after treatment with a mixture of specific amino acids.

It has been shown that B. cereus has germination enhancements when treated with a mixture of inosine and L-alanine as a $0.1 \mathrm{mM}$ solution. In our opinion, the allosteric effect of inosine and L-alanine is explained by the binding between the specific Ger- receptors, which are extremely important for spore germination.

Carrying out studies on the vaccine strain of the B. anthracis, we used different combinations of amino acids to study possible ways to improve spore germination. The best results were obtained using inosine and L-serine, as well as inosine with L-alanine and L-valine $(0.1 \mathrm{mM}$ aqueous solution of an equal ratio of amino acids was used).

Analysis of the results of the studies showed that the part of spores, germinated in nutrient media, after treatment with a mixture of aminoacids reached $86.2 \%$ compared with $58 \%$ in the control. The variability of these values for tested strains ranged from $\pm 3.8 \%$ to $\pm 13.6 \%$. 
We also found that the percentage of germinated spores does not increase significantly in time after the first 48 hours from the start of cultivation (Fig. 1 and 2).

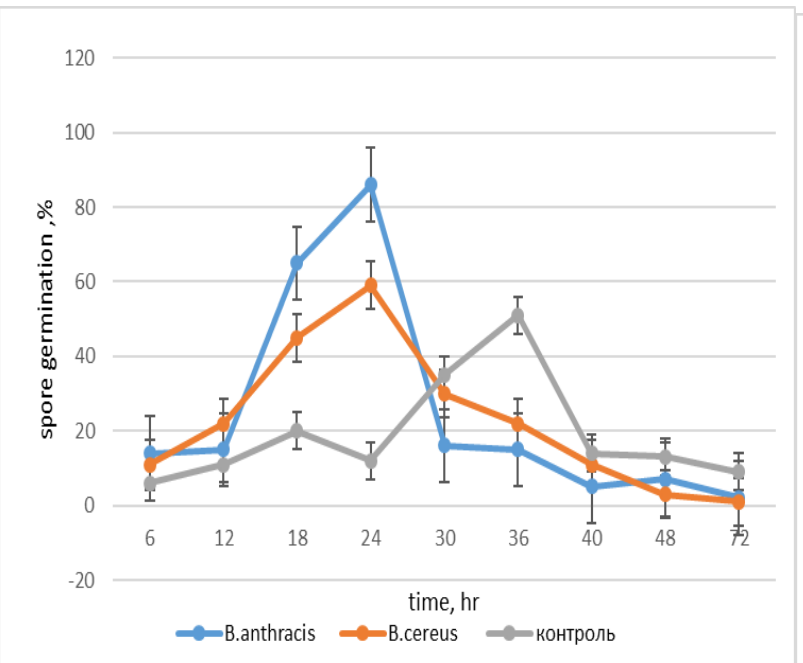

Fig. 1 The impact of inosine and L-serine mix $(0,1 \mathrm{mM}$ concentration) onto spore germination.

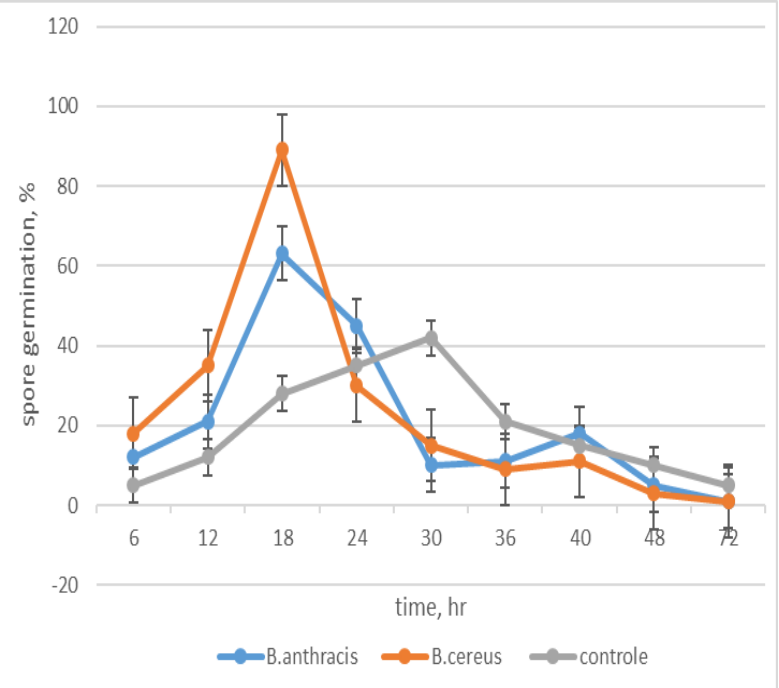

Fig. 2 The impact of inosine and L-alanine mix $(0,1 \mathrm{mM}$ concentration) onto spore germination.

In conclusion, germination kinetics can determine the spores' affinity to its germinant and maximum rate of germination.

The new data revealed in this study can be used for creating new approaches for decontamination of old anthrax burial ground by using germinants with specific desinfecting agents.

Conclusions and prospects for further research. As a result of the studies, it has been established that $B$. cereus and B. anthracis spores had the best germination conditions after treatment with a mixture of specific amino acids. It has been shown that $B$. cereus spores has increased germination (from 32 to 86,2\%) for treatment with inosine mixture with L-alanine in the form of $0.1 \mathrm{mM}$ solution. Among the 10 different amino acid combinations, the best results for the germination of the B. anthracis vaccine strain spores were obtained using inosine and L-serine, as well as inosine with L-valine.

The results are planned to be used to develop new approaches to the decontamination of anthrax burial ground.

\section{REFERENCES}

1. Dragon, D.C., Bader, D.E., Mitchell, J., \& Woollen, N. (2005). Natural dissemination of Bacillus anthracis spores in northern Canada. Applied and Environmental Microbiology, 71(3), 1610-1615.

2. Bezymennyi, M., Bagamian, K.H., Barro, A., Skrypnyk, A., Skrypnyk, V., \& Blackburn, J.K. (2014). Spatio-temporal patterns of livestock anthrax in Ukraine during the past century (19132012). Appl. Geogr., 54, 129-138.

3. Jensen, G. B., Hansen, B. M., Eilenberg, J., \& Mahillon, J. (2003). The hidden lifestyles of Bacillus cereus and relatives. Environmental Microbiology, 5(8), 631-640.

4. Gould, G.W. (1977). Recent advances in the understanding of resistance and dormancy in bacterial spores. Journal of Applied Bacteriology, 42(3), 297-309. 
5. Fisher, N., \& Hanna, P. (2005). Characterization of Bacillus anthracis germinant receptors in vitro. Journal of Bacteriology, 187(23), 8055-8062.

6. Kaneko, T., Nozaki, R. \& Aizawa, K. (1978). Deoxyribonucleic acid relatedness between Bacillus anthracis, Bacillus cereus, and Bacillus thuringiensis. Microbiol Immunol, 22, 639-641.

7. Somerville, H. J., \& Jones, M. L. (1972). DNA competition studies within the Bacillus cereus group of bacilli. Journal of General Microbiology, 73(2), 257-265.

8. Hornstra, L. M., De Vries, Y. P., De Vos, W. M., \& Abee, T. (2006). Influence of sporulation medium composition on transcription of ger operons and the germination response of spores of Bacillus cereus ATCC 14579. Applied and Environmental Microbiology, 72(5), 37463749.

9. Fey, C., Gould G.W., \& Hitchins A.D. (1964). Identification of D-alanine as the autoinhibitor of germination of Bacillus globigii spores. J. Gen. Microbiol., 35, 229-236.

10. Barlass, P. J., Houston, C. W., Clements, M. O., \& Moir, A. (2002). Germination of Bacillus cereus spores in response to L-alanine and to inosine: The roles of gerL and gerQ operons. Microbiology, 148(7), 2089-2095.

11. Clements, M. O., \& Moir, A. (1998). Role of the geri operon of Bacillus cereus 569 in the response of spores to germinants. Journal of Bacteriology, 180(24), 6729-6735.

12. Ireland, J.A.W., \& Hanna, P.C. (2002). Amino acid- and purine ribonucleosideinduced germination of Bacillus anthracis Sterne endospores: GerS mediates responses to aromatic ring structures. Journal of Bacteriology, 184(5), 1296-1303.

13. Abel-Santos, E., Dodatko, T. (2007). Differential nucleoside recognition during Bacillus cereus 569 (ATCC 10876) spore germination. New Journal of Chemistry, 31(5), 748-755.

14. Guidi-Rontani, C., Pereira, Y., Ruffie, S., Sirard, J., Weber-Levy, M., \& Mock, M. (1999). Identification and characterization of a germination operon on the virulence plasmid pXOI of Bacillus anthracis. Molecular Microbiology, 33(2), 407-441.

\section{ВЛИЯНИЕ АМИНОКИСЛОТ НА ПРОРАСТАНИЕ СПОР БАКТЕРИЙ РОДА}

BACILLUS / Крыленко С.Ю., Тарасов О.А., Гудзь Н.В., Бабкіна М.М., Терещенко С.М.

В исследованиях мы использовали комбинации аминокислот для изучения возможных путей улучшения прорастания спор. Наилучшие результатьл были получень $c$ использованием инозина и L-серина, а также инозина с L-аланином (использовали 0,1 мM водный раствор с равным соотношением аминокислот).

Анализ результатов исследований показал, что часть спор, проросших в питательных средах, после обработки смесью аминокислот достигла 86,2\% по сравнению с $58 \%$ в контроле. Изменчивость этих значений для тестируемых штаммов варьировала от \pm $3,8 \%$ до $\pm 13,6 \%$.

Mbl также обнаружили, что процент прорастающих спор не увеличивается значительно по прошествии первых 48 часов с начала культивирования.

В результате исследований было установлено, что сnоры B. cereus $u$ B. anthracis имели лучшие условия прорастания после обработки смесью определенных аминокислот. Было показано, что споры В. сегеия увеличивают прорастание (от 32 до 86,2\%) при обработке смесью инозина с L-аланином в виде 0,1 мМ раствора. Cреди 10 различных комбинаций аминокислот лучшие результаты для прорастания спор вакцинного штамма $B$. anthracis были получены с использованием инозина и L-серина, а также инозина c L-валином.

Результаты планируется использовать для разработки новых подходов $к$ дезактивации могильника сибирской язвы.

Ключевье слова: прорастание спор, бактерии рода Bacillus, аминокислоть,, герминант. 


\section{ВПЛИВ АМІНОКИСЛОТ НА ПРОРОСТАННЯ СПОР БАКТЕРІЙ РОДУ} BACILLUS / Криленко С.Ю., Тарасов О.А., Гудзь Н.В., Бабкіна М.М., Терещенко С.М.

Bcmyn. B. anthracis $\epsilon$ збудником сибіки, небезпечної хвороби людей і тварин, особливо жуйних. Тварини можуть бути інфіковані через спори у забруднених пасовищах, забруднених кормах або інфікованими тушами. Люди можуть заражатися через контакт із зараженими тваринами або забрудненими продуктами тваринного походження. $B$ Україні навіть на початку ХХІ століття сибірка є актуальною проблемою для людей та тварин по всій країні, яка походить з історії. До 1970-х років, особливо на початку століття та після Другої світової війни, сибірка була поширеною хворобою в краӥні $з$ великою кількістю постійних вогнищ. На жаль, назви і місия багатьох з них були втрачені протягом багатьох років.

Мета роботи. Вивчити вплив амінокислот на проростання спор B. cereus та B. anthracis, використовуючи тести in vitro.

Матеріали та методи дослідження. У дослідженні були використані штами Bacillus anthracis (UA 07), Bacillus cereus (ATCC 10702) з колекиії Інституту ветеринарної медицини НАAH.

Бактеріальні штами вирощували в поживному середовищі та культували на агарі (BioRad). Чисті культури готували на агарі культивуванням за температури $37^{\circ} \mathrm{C}$ протягом 5 днів.

Екстракція бактеріальних ендоспор та скринінг здійснювалась у лабораторії 3 вивчення сибірки ІВМ відповідно до керівництва МЕБ (2004) та СОП. Культуру у пробіриі в кількості 5,0 мл обробляли 70\% етанолом для дезактивації всіх вегетативних форм мікроорганізмів, протягом 10 хвилин. Потім додавали 5 мл фізіологічного розчину $i$ струшували протягом 5 хв. Після цьього суспензію центрифугували протягом 2-3 хв при 3000 об/хв. Декантовану суспензію використовували для подальших випробувань.

Кількість досліджуваного інокуляту становила приблизно $2 \times 10^{3} \mathrm{KУO} / \mathrm{мл.}$

Оскільки спори мають дуже щъільну структуру, вони сильно розсіюють світло. При проростанні спора насичується водою, що зменшує розсіювання світла. Ця властивість використовувалася для вимірювання проростання суспензії спор за рахунок зменшення оптичної щуільності при 540 нм (OD540). Суспензію спор розводили до $10^{-6}$ розчину, після обробки висівали на агар та інкубували протягом 48 годин з наступним підрахунком кількості колоній. В дослідах використовували амінокислоти: L-пролін, L-аланін, L-гістидин, L-триптофан, L-тирозин, L-фенілаланін, L-валін та інозин.

Результати досліджень та їх обговорення. В результаті проведених досліджень було встановлено, щзо B. cereus ma B. anthracis мають підвищені властивості проростання після обробки сумішшю специифічних амінокислот. Було показано, щзо В. сегеиs підвищує проростання після оброблення сумішшю інозину та L-аланіну як 0,1 мM розчину. На нашу думку, підсилюючий ефект інозину i L-аланіну пояснюється зв'язуванням між специфічними Ger-рецепторами, щзо є надзвичайно важливим для проростання спор.

Досліджуючи вакцинний штам B. anthracis, ми використовували 5 різних комбінацій амінокислот для вивчення можливих шляхів покращення проростання спор. Найкращі результати були отримані з використанням інозину та L-серину, а також інозину з Lваліном (використовували 0,1 мМ водний розчин рівної кількості амінокислот).

Аналіз результатів досліджень показав, що частина спор, що проросла у поживних середовищах, після обробки сумішшю амінокислот досягла 86,2\% у порівнянні з 58\% у контролі. Варіативність ичих значень для випробуваних штамів коливалася від $\pm 3,8 \%$ до \pm $13,6 \%$.

Ми також виявили, щуо відсоток пророщених спор суттєво не зростає з часом після перших 48 годин від початку культивування.

Висновки та персективи подальших досліджень. В результаті досліджень було встановлено, щчо спори B. сегеus та B. anthracis мали найкращі умови пророщування після 
обробки сумішшю специффічних амінокислот. Показано, щзо спори В. сегеи підвищують проростання (від 32 до 86\%) при обробиі сумішшю ізозину з L-аланіном у формі розчину 0,1 мМ. Серед 10 різних комбінацій амінокислот найкращі результати проростання спор вакцинного штаму B. anthracis були отримані з використанням інозину та L-серину, a також інозину з L-валіном.

Результати планується використати для розробки нових підходів до деконтамінаиії місиь сибіркових поховань.

Ключові слова: прорастання спор, бактерії роду Bacillus, амінокислоти, гермінант.

\section{СПИСОК ЛІТЕРАТУРИ}

1. Dragon D.C. Natural dissemination of Bacillus anthracis spores in northern Canada / D.C. Dragon, D.E. Bader, J. Mitchell, N. Woollen // Applied and Environmental Microbiology. 2005. - № 71(3). - P. 1610-1615.

2. Bezymennyi M. Spatio-temporal patterns of livestock anthrax in Ukraine during the past century (1913-2012) / M. Bezymennyi, K.H. Bagamian, A. Barro, A. Skrypnyk, V. Skrypnyk, J.K. Blackburn // Appl. Geogr. - 2014. - № 54. - P. 129-138.

3. Jensen G.B. The hidden lifestyles of Bacillus cereus and relatives / G.B. Jensen, B.M. Hansen, J. Eilenberg, J. Mahillon // Environmental Microbiology. - 2003. - № 5(8). - P. 631-640.

4. Gould G.W. Recent advances in the understanding of resistance and dormancy in bacterial spores / G.W. Gould // Journal of Applied Bacteriology. - 1977. - № 42(3). - P. 297-309.

5. Fisher N. Characterization of Bacillus anthracis germinant receptors in vitro / N. Fisher, P. Hanna // Journal of Bacteriology. - 2005. - № 187(23). - C. 8055-8062.

6. Kaneko T. Deoxyribonucleic acid relatedness between Bacillus anthracis, Bacillus cereus, and Bacillus thuringiensis / T. Kaneko, R. Nozaki, K. Aizawa // Microbiol Immunol. 1978. - № 22. - P. 639-641.

7. Somerville H.J. DNA competition studies within the Bacillus cereus group of bacilli / H.J. Somerville, M.L. Jones // Journal of General Microbiology. - 1972. - 73(2). - P. 257-265.

8. Hornstra L.M. Influence of sporulation medium composition on transcription of ger operons and the germination response of spores of Bacillus cereus ATCC 14579 / L.M. Hornstra, Y.P. De Vries, W.M. De Vos, T. Abee // Applied and Environmental Microbiology. - 2006. - № 72(5). - P. 3746-3749.

9. Fey C. Identification of D-alanine as the auto-inhibitor of germination of Bacillus globigii spores / C. Fey, G.W. Gould, A.D. Hitchins // J. Gen. Microbiol. -1964. - № 35. - C. 229-236.

10. Barlass P.J. Germination of Bacillus cereus spores in response to L-alanine and to inosine: The roles of gerL and gerQ operons / Barlass P.J., Houston C.W., Clements M.O., \& Moir A. // Microbiology. - 2002. - № 148(7). - P. 2089-2095.

11. Clements M.O. Role of the geri operon of Bacillus cereus 569 in the response of spores to germinants / M.O. Clements, A. Moir // Journal of Bacteriology. - 1998. - 180(24). - P. 67296735.

12. Ireland, J.A.W. Amino acid- and purine ribonucleosideinduced germination of Bacillus anthracis Sterne endospores: GerS mediates responses to aromatic ring structures / Ireland J.A.W., Hanna P.C. // Journal of Bacteriology. - 2002. - 184(5). - P. 1296-1303.

13. Abel-Santos E. Differential nucleoside recognition during Bacillus cereus 569 (ATCC 10876) spore germination / Abel-Santos E., Dodatko T. // New Journal of Chemistry. - 2007. - № 31(5). - P. 748-755.

14. Guidi-Rontani C. Identification and characterization of a germination operon on the virulence plasmid pXOI of Bacillus anthracis / Guidi-Rontani C., Pereira Y., Ruffie S. Sirard, J. Weber-Levy, M. Mock // Molecular Microbiology. - 1999. - № 33(2). - P. 407-441 